\title{
Pengaruh Model Pembelajaran Inkuiri Terbimbing Berbantuan Alat Praktikum Sederhana Terhadap Keterampilan Berpikir Kritis Siswa Kelas VIII SMP Negeri 16 Palu
}

\author{
Delpina Nggolaon, I Wayan Darmadi, dan Muhammad Ali \\ delfhynanggolaon@gmail.com \\ Program Studi Pendidikan Fisika FKIP Universitas Tadulako \\ Jl. Soekarno Hatta Km. 9 Kampus Bumi Tadulako Tondo Palu - Sulawesi Tengah
}

\begin{abstract}
Abstrak - Penelitian ini bertujuan untuk mengetahui ada tidaknya pengaruh model pembelajaran inkuiri terbimbing berbantuan alat praktikum sederhana terhadap keterampilan berpikir kritis siswa kelas VIII SMP Negeri 16 Palu. Jenis penelitian ini merupakan kuasi eksperimen dengan desain equivalent pretest-posttest. Populasi penelitian adalah siswa kelas VIII SMP Negeri 16 Palu. Pengambilan sampel dilakukan secara purposive sampling dengan sampel penelitian adalah kelas VIII B sebagai kelas eksperimen dan kelas VIII C sebagai kelas kontrol. Instrumen penelitian berupa tes keterampilan berpikir kritis serta lembar observasi guru yang telah divalidasi oleh validator. Peningkatan rata-rata n-gain pada kelas eksperimen adalah 54,0 sedangkan pada kelas kontrol adalah 43,0. Nilai signifikansi hasil uji hipotesis diperoleh lebih besar dibandingkan dengan nilai t tabel atau 8,51 > 1,67, sehingga $\mathrm{H}_{1}$ diterima dan $\mathrm{H}_{0}$ ditolak. Hasil ini menunjukkan bahwa terdapat pengaruh model pembelajaran inkuiri terbimbing berbantuan alat praktikum sederhana terhadap keterampilan berpikir kritis siswa kelas VIII SMP Negeri 16 Palu.
\end{abstract}

Kata Kunci: Pembelajaran Inkuiri Terbimbing, Keterampilan Berpikir Kritis, Alat Praktikum Sederhana

\section{PENDAHULUAN}

Fisika merupakan salah satu mata pelajaran dalam rumpun sains. Para ahli memandang sains tidak hanya terdiri dari fakta, konsep, dan teori yang dihafalkan tetapi menggunakan pikiran dan sikap ilmiah dalam mempelajari ilmu alam yang belum dapat diterangkan. Dengan demikian dalam pelaksanaan pembelajaran fisika siswa tidak hanya menghafal namun terus memperoleh pembelajaran secara aktif melalui berbagai kegiatan sains.

Namun kenyataan yang di temui banyak guru menggunakan pembelajaran konvensional yang mengakibatkan siswa menjadi kurang aktif dan terlibat secara langsung dalam pembelajaran. Padahal Guru dalam proses pembelajaran baiknya memberikan bimbingan dan kesempatan bagi siswa untuk berkembang secara mandiri melalui penemuan dan berpikir kritis. Seperti yang dinyatakan bahwa salah satu kecakapan hidup (life skill) yang perlu dikembangkan melalui proses pendidikan adalah keterampilan berpikir [1].

Berpikir kritis yaitu memberdayakan keterampilan atau strategi kognitif dalam menentukan tujuan. Dimana proses tersebut di Ialui setelah menentukan tujuan yang merupakan bentuk berpikir yang perlu dikembangkan dalam rangka memecahkan masalah, merumuskan kesimpulan, mengumpulkan berbagai kemungkinan, dan membuat keputusan ketika menggunakan semua keterampilan tersebut secara efektif dalam konteks dan tipe yang tepat. Berpikir kritis juga merupakan kegiatan mengevaluasi serta mempertimbangkan kesimpulan yang akan di ambil manakala menentukan beberapa faktor pendukung untuk membuat keputusan [2].

Kurangnya memberikan keterampilan berpikir kritis dalam proses pembelajaran dapat mengarahkan siswa pada kebiasaan melakukan berbagai kegiatan tanpa mengetahui tujuan dan mengapa mereka melakukannya. Padahal di dalam era global yang penuh dengan tantangan dan perubahan yang serba cepat terjadi sekarang ini, siswa membutuhkan keterampilan mengembangkan konsep berpikir kritis [3].

Terkait dengan hal tersebut, yaitu untuk mengupayakan peningkatan kemampuan berpikir kritis siswa di perlukan suatu model pembelajaran yang lebih memberdayakan siswa, yang mampu menarik minat dan kreatifitas berpikir siswa dalam belajar, yang dapat melibatkan siswa secara langsung dalam kegiatan pembelajaran. Salah satu model pembelajaran yang terkait yaitu model pembelajaran inkuiri terbimbing. Inkuiri merupakan model pembelajaran yang mengacu 
pada suatu cara untuk mempertanyakan, mencari pengetahuan, informasi atau suatu gejala. Apabila siswa belum pernah mempunyai pengalaman belajar dengan kegiatan-kegiatan inkuiri, maka diperlukan bimbingan yang cukup luas dari guru. Hal inilah yang disebut dengan inkuiri terbimbing [4].

Berdasarkan uraian di atas, maka dilakukan penelitian "apakah terdapat pengaruh model pembelajaran inkuiri terbimbing berbantuan alat praktikum sederhana terhadap keterampilan berpikir kritis siswa kelas VIII SMP negeri 16 Palu".

\section{METODE PENELITIAN}

Jenis penelitian ini adalah kuasi eksperimen dengan desain penelitian menggunakan "Equivalen Pretest-Posttest Design (Rancangan Prates-Pascates yang Ekuivalen).".

Desain penelitian ini digambarkan pada Tabel 1. [5]

TABEL 1 DESAIN PENELITIAN

\begin{tabular}{lccc}
\multicolumn{1}{c}{ Kelas } & Tes awal & Perlakuan & Tes akhir \\
\hline Eksperimen & $\mathrm{O}$ & $\mathrm{X}_{1}$ & $\mathrm{O}$ \\
Kontrol & $\mathrm{O}$ & $\mathrm{X}_{2}$ & $\mathrm{O}$ \\
\hline
\end{tabular}

Keterangan :

$\mathrm{X}_{1}$ : model pembelajaran inkuiri terbimbing berbantuan alat praktikum sederhana

$\mathrm{X}_{2}$ : pembelajaran konvensional model direct instruction

O : tes awal sama dengan tes akhir

Penelitian dilakukan di SMP Negeri 16 Palu. Populasi dalam penelitian ini adalah seluruh siswa kelas VIII SMP Negeri 16 Palu tahun pelajaran 2015/2016 yang terdiri dari 6 kelas. Sampel dalam penelitian ini adalah kelas VIII B yang berjumlah 30 siswa dan VIII C yang berjumlah 30 siswa. Teknik pengambilan sampel yang digunakan adalah purposive sampling, yaitu teknik penentuan sampel dengan pertimbangan tertentu.

Instrumen yang digunakan dalam penelitian ini adalah tes keterampilan berpikir kritis yang telah divalidasi oleh validator ahli. Analisis data hasil penelitian menggunakan uji normalitas, uji homogenitas, uji hipotesis (uji-t), dan uji ngain.

\section{HASIL DAN PEMBAHASAN}

\section{A. Hasil Penelitian}

Pada penelitian ini proses validasi dilakukan oleh validator ahli. Dimana soal yang telah dibuat dikonsultasikan kepada validator ahli. Instrumen soal yang dibuat berjumlah 8 soal, kemudian berdasarkan hasil validitas ahli disetujui 7 soal yang selanjutnya 7 soal tersebut digunakan sebagai soal pretest dan postest pada siswa kelas VIII SMP Negeri 16 Palu.

Berdasarkan hasil pemberian pretest dan posttest pada kelas eksperimen yang berjumlah 30 siswa dan kelas kontrol yang berjumlah 30 siswa diperoleh nilai maksimum, nilai minimum, nilai rata-rata dan simpangan baku seperti terlihat pada Tabel 2.

TABEL 2 DESKRIPSI SKOR TES KETERAMPILAN BERPIKIR KRITIS UNTUK KELAS EKSPERIMEN DAN KELAS KONTROL

\begin{tabular}{lcccc}
\hline \multirow{2}{*}{ Uraian } & \multicolumn{2}{l}{ Preetest } & \multicolumn{3}{c}{ Posttest } \\
\cline { 2 - 5 } & Eksperimen & Kontrol & Eksperimen & Kontrol \\
\hline $\begin{array}{l}\text { Sampel } \\
(\mathrm{n})\end{array}$ & 30 & 30 & 30 & 30 \\
$\begin{array}{l}\text { Nilai } \\
\text { maksimum }\end{array}$ & 17 & 18 & 26 & 25 \\
$\begin{array}{l}\text { Nilai } \\
\text { minimum } \\
\begin{array}{l}\text { Skor rata- } \\
\text { rata } \\
\text { Standar }\end{array}\end{array}$ & 11,30 & 11,63 & 20,50 & 18,63 \\
deviasi & 2,73 & 3,19 & 3,35 & 3,32 \\
\hline
\end{tabular}

Hasil perhitungan analisis uji normalitas Pretest dan Posttest dapat dilihat pada Tabel 3.

TABEL 3 HASIL UJI NORMALITAS PRETEST DAN POSTTEST KELAS EKSPERIMEN DAN KELAS KONTROL

\begin{tabular}{|c|c|c|c|c|}
\hline \multirow{2}{*}{ Uraian } & \multicolumn{2}{|l|}{ Preetest } & \multicolumn{2}{|c|}{ Posttest } \\
\hline & Eksperimen & Kontrol & $\begin{array}{l}\text { Eksperim } \\
\text { en }\end{array}$ & Kontrol \\
\hline Nilai $\chi^{2}$ hitung & 2,79 & 7,22 & 4,85 & 7,29 \\
\hline Nilai $\chi^{2}$ tabel & 7,81 & 7,81 & 7,81 & 7,81 \\
\hline Keputusan & distribusi & distribusi & distribusi & distribusi \\
\hline & normal & normal & normal & normal \\
\hline
\end{tabular}

Berdasarkan hasil uji normalitas pada tabel 3 dengan derajat kebebasan $\mathrm{dk}=\mathrm{k}-3=6-3=$ 3 dengan peluang $(1-\alpha)=1-0,05=0,95$ pada taraf signifikansi $\alpha=0,05$, diperoleh nilai $\mathrm{X}^{2}$ Hitung untuk pretest kelas eksperimen dan kontrol masing-masing 2,79 dan 7,22, sedangkan nilai $\mathrm{X}^{2}$ Hitung untuk postest kelas eksperimen dan kontrol masing-masing 4,85 dan 7,29 dengan $X^{2}$ tabel 7,81 sehingga $X^{2}$ Hitung $<X^{2}$ tabel. Sesuai kriteria pengambilan keputusan, maka baik data pretest dan posttest dari kelas eksperimen maupun kelas kontrol keduanya berasal dari populasi yang terdistribusi normal.

Hasil perhitungan analisis uji homogenitas Pretest dan postest dapat dilihat pada Tabel 4.

TABEL 4. HASIL UJI HOMOGENITAS PRETEST DAN POSTEST

\begin{tabular}{ccc}
\hline Uraian & Pretest & Posttest \\
\hline Nilai F Hitung & 1,44 & 1,02 \\
Nilai F tabel $(a=0,05)$ & 1,84 & 1,84 \\
Keputusan & Homogen & Homogen \\
\hline
\end{tabular}


Berdasarkan hasil uji homogenitas pada tabel 4, dengan derajat kebebasan untuk pembilang $\left(n_{1}\right)=30$ dan penyebut $\left(n_{2}\right)=30$ pada taraf signifikansi $\alpha=0,05$, maka nilai $F_{\text {tabel }}$ diperoleh sebesar $F_{0,05(30,30)}=1,84$ dan nilai ini lebih besar dari nilai $F_{\text {hitung }}$ baik nilai Pretest dan postest yaitu 1,44 dan 1,02. Berdasarkan kriteria pengambilan keputusan, diketahui data tersebut memiliki varians yang sama atau homogen.

Hasil perhitungan analisis uji beda rata-rata (satu pihak) pretest menunjukkan bahwa ratarata skor keterampilan berpikir kritis siswa yang belajar dengan model pembelajaran inkuiri terbimbing berbantuan alat praktikum sederhana sama dengan rata-rata skor keterampilan berpikir kritis siswa yang belajar dengan model pembelajaran direct instruction. Sehingga dapat disimpulkan bahwa siswa pada kelas eksperimen dan kelas kontrol memiliki kemampuan awal yang sama.

Hasil perhitungan analisis uji beda rata-rata (satu pihak) Postest dapat dilihat pada Tabel 5.

TABEL 5. UJI BEDA RATA-RATA (SATU PIHAK) POSTEST KELAS EKSPERIMEN

\begin{tabular}{|c|c|c|c|c|}
\hline Kelas & $\begin{array}{c}\text { Nilai rata- } \\
\text { rata } \bar{X}\end{array}$ & $t_{\text {hitung }}$ & $t_{\text {tabel }}$ & Keputusan \\
\hline Eksperimen & 20,50 & \multirow{2}{*}{8,56} & \multirow{2}{*}{2,00} & \multirow{2}{*}{$\begin{array}{c}\mathrm{H}_{1} \\
\text { diterima }\end{array}$} \\
\hline Kontrol & 18,63 & & & \\
\hline
\end{tabular}

Berdasarkan data Tabel 5 dan kriteria pengujian dimana $\mathrm{H}_{0}$ ditolak jika $\mathrm{t} \geq \mathrm{t}_{(1-\mathrm{a})}$ dapat dilihat nilai thitung berada di luar daerah penerimaan $\mathrm{H}_{0}$. Dengan demikian $\mathrm{H}_{0}$ ditolak dan $\mathrm{H}_{1}$ diterima. Dengan kata lain, rata-rata skor keterampilan berpikir kritis siswa yang belajar dengan model pembelajaran inkuiri terbimbing berbantuan alat praktikum sederhana lebih besar dari rata-rata skor keterampilan berpikir kritis siswa yang belajar dengan model pembelajaran direct instruction. Sehingga dapat disimpulkan bahwa siswa pada kelas eksperimen dan kelas kontrol memiliki kemampuan akhir yang berbeda.

Hasil uji peningkatan keterampilan berpikir kritis siswa dapat dilihat pada Tabel 6

TABEL 6 HASIL UJI PENINGKATAN KETERAMPILAN BERPIKIR KRITIS KELAS

\begin{tabular}{|c|c|c|c|}
\hline Kelas & Pretest & Posttest & $\begin{array}{l}\text { Rata-rata } \\
\text { gain }(\%)\end{array}$ \\
\hline Eksperimen & 11,30 & 20,50 & 54,00 \\
\hline Kontrol & 11,63 & 18,63 & 43,00 \\
\hline
\end{tabular}

Berdasarkan Tabel 6 dapat dilihat perbedaan peningkatan keterampilan berpikir kritis siswa antara kelas eksperimen dan kelas kontrol. Hal ini menunjukkan bahwa rata-rata peningkatan keterampilan berpikir kritis siswa pada kelas eksperimen lebih tinggi dari pada kelas kontrol. Walaupun dari kriteria n-gain sendiri keduanya termasuk dalam kategori sedang, namun pada kelas eksperimen terdapat lebih banyak siwa yang memiliki nilai n-gain yang tinggi dibandingkan siswa pada kelas kontrol. Hal ini menunjukkan peningkatan keterampilan berpikir kritis siswa pada kelas eksperimen yang menggunakan model pembelajaran inkuiri terbimbing berbantuan alat praktikum sederhana lebih timggi dari pada kelas kontrol yang menggunakan pembelajaran konvensional dengan model pembelajaran direct instruction.

Tingkat ketercapaian $\mathrm{n}$-gain untuk setiap indikator keterampilan berpikir kritis dapat dilihat pada gambar 1 .

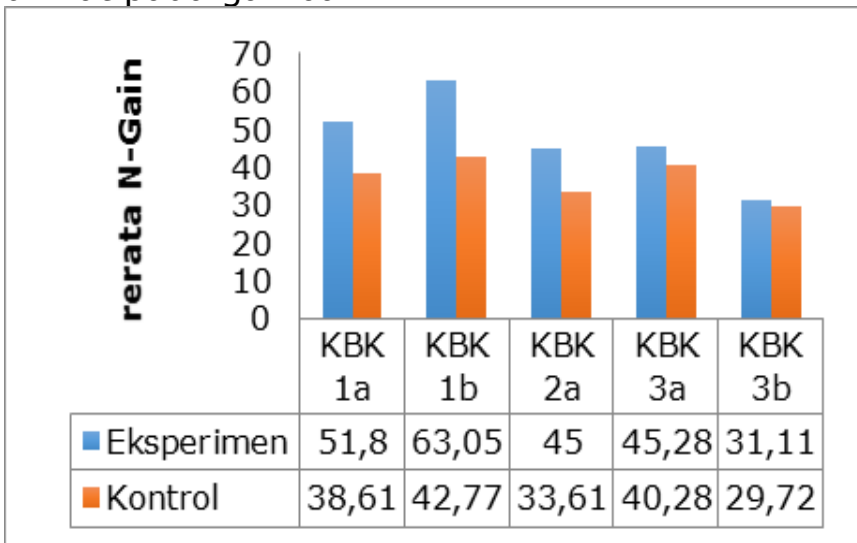

Gbr. 1.Tingkat ketercapaian n-gain indikator KBK kelas eksperimen dan kelas kontrol

Berdasarkan gambar 1 dapat dilihat bahwa n-gain yang paling tinggi peningkatannya terlihat pada indikator KBK 1b yaitu menganalisis argumen sedangkan indikator yang rendah peningkatannya terlihat pada indikator $\mathrm{KBK} 3 \mathrm{~b}$ yaitu menginduksi dan mempertimbangkan hasil induksi.

\section{B. Pembahasan}

Berdasarkan hasil analisis data, diperoleh rata-rata nilai tes awal keterampilan berpikir kritis siswa pada materi gaya dan hukum Newton untuk kelas eksperimen dan kontrol, masing-masing yaitu 11,30 dan 11,63. Hasil tersebut menunjukkan bahwa keterampilan berpikir kritis kedua kelas hampir sama sebelum diberi perlakuan. Hal ini pula disebabkan kedua kelas sama-sama distribusinya merata dan kedua kelas belum mendapatkan pembelajaran tentang materi gaya dan hukum Newton.

Setelah melakukan tahap pembelajaran hingga materi berakhir, selanjutnya siswa diberikan tes akhir (posttest) dengan soal yang sama dengan tes awal yang sebelumnya telah diujikan. Tes akhir (posttest) diberikan untuk mengetahui kemampuan akhir siswa di kedua 
kelas dan sebagai data analisis penelitian yang selanjutnya digunakan sebagai pembanding untuk mengetahui peningkatan keterampilan berpikir kritis antara kedua kelas tersebut.

Setelah diberi perlakuan pembelajaran pada kelas eksperimen dan kontrol, keduanya memperoleh nilai yang meningkat dari keadaan awal. Hal tersebut dapat dilihat melalui hasil analisis menggunakan uji n-gain dengan kriteria tinggi, sedang, dan rendah, yaitu diperoleh keterampilan berpikir kritis siswa kelas eksperimen yang lebih tinggi dari pada kelas kontrol. Meskipun rata-rata peningkatan kedua kelas termasuk dalam kategori sedang namun pada kelas eksperimen terdapat lebih banyak siswa yang memiliki n-gain yang tinggi dibandingkan siswa pada kelas kontrol. Pada kelas eksperimen diperoleh rata-rata $\mathrm{N}$-gain dengan 7 siswa kriteria tinggi, 21 siswa kriteria sedang, dan 2 siswa kriteria rendah. Sedangkan pada kelas kontrol diperoleh rata-rata $\mathrm{N}$-gain dengan 2 siswa kriteria tinggi, 24 siswa kriteria sedang, dan 4 siswa kriteria rendah.

Hasil ini kemudian didukung dengan adanya uji hipotesis yaitu uji-t satu pihak. Dari hasil analisa dan tes akhir yang ada diperoleh bahwa $\mathrm{H}_{1}$ diterima dengan kata lain terdapat perbedaan rata-rata skor antara model pembelajaran inkuiri terbimbing berbantuan alat praktikum sederhana dengan pembelajaran konvensional menggunakan model direct instruction dalam meningkatkan keterampilan berpikir kritis. Hal ini dikarenakan pada kelas eksperimen dilakukan sebuah pengajaran dimana siswa akan lebih aktif dalam pembelajaran dan memecahkan masalah yang diberikan, ditambah dengan menggunakan alat praktikum sederhana lebih membuat proses belajar mengajar dikelas lebih aktif dan menyenangkan sehingga siswa akan lebih memahami materi yang diajarkan.

Tahapan pembelajaran yang membuat keterampilan berpikir kritis kelas eksperimen meningkat adalah pada tahap kedua yaitu guru membagikan LKS untuk selanjutnya dikerjakan oleh siswa. Setelah LKS telah dibagikan, guru akan menjelaskan masalah yang disajikan tersebut. Setelah guru menjelaskan secara rinci, maka tugas selanjutnya ada pada siswa untuk mulai mendiskusikan dengan teman kelompoknya dalam menyelesaikan masalah yang diberikan. Perumusan masalah ini dibuat dalam bentuk pertanyaan permasalahan, yang bertujuan untuk menggali pemahaman awal siswa terhadap materi gaya dan hukum Newton. Setelah itu siswa menetapkan jawaban sementara atau hipotesis. Pada tahap ini siswa dalam kelompok dituntut memberikan dan menuliskan jawaban sementara dari permasalahan yang telah diberikan, berdasarkan pemahaman mereka sendiri dari hasil diskusi. Langkah selanjutnya siswa mencari data, fakta, yang diperlukan untuk menjawab permasalahan atau hipotesis dengan melakukan praktikum yang sesuai dengan masalah tersebut menggunakan alat praktikum sederhana yang telah disediakan dengan bimbingan langsung dari guru. Selanjutnya siswa menggali informasi mengenai temuan mereka untuk kemudian di isi dalam LKS. Setelah siswa melakukan tiap percobaan dalam praktikum guru membimbing siswa dalam menguji serta mengklarifikasi hipotesis sebelumnya.

Ketika pembelajaran diatas berlangsung, siswa lebih cenderung mengerjakan masalah yang diberikan oleh guru, saat siswa diberikan pertanyaan permasalahan, siswa langsung berdiskusi dengan teman sekelompoknya untuk merumuskan hipotesis berdasarkan pengetahuan awal mereka, bahkan saat diskusi ada beberapa kelompok yang ribut karena saling mempertahankan pendapat masingmasing. Siswa juga melaksanakan praktikum menggunakan alat sederhana untuk mendapatkan jawaban dari masalah berdasarkan fakta dengan bimbingan dari guru. Hal ini menunjukkan bahwa siswa lebih bersemangat dan lebih aktif dalam proses belajar. Selain itu, dengan adanya jawaban yang tepat dari hasil praktikum akan mengklarifikasi hipotesis siswa sebelumnya yang masih keliru. Hal inilah yang membuat siswa lebih memahami dengan benar materi pelajaran yang diajarkan.

Berbeda dengan kelas kontrol, model pembelajaran yang diterapkan yaitu pembelajaran konvensional dengan model direct instruction sebagai pembanding kelas eksperimen yang menggunakan model inkuiri terbimbing berbantuan alat praktikum sederhana, siswa dalam kegiatan pembelajaran konvensional ini kurang aktif dalam kegiatan pembelajaran, hal ini menyebabkan banyak siswa yang mengantuk dalam kelas sehingga tidak menyimak dengan jelas penjelasan materi yang diberikan oleh guru. Hal ini juga dapat mempengaruhi keterampilan berpikir kritis siswa karena siswa tidak secara aktif dan kreatif dalam proses pembelajaran yang seharusnya siswa lebih banyak berperan.

Kenaikan yang paling signifikan berdasarkan indikator keterampilan berpikir kritis yang diukur adalah pada saat siswa menganalisis argumen, sedangkan untuk menginduksi dan mempertimbangkan hasil induksi masih kurang. Hal ini dapat terjadi karena perbedaan kesulitan ditiap soal yang ada. Pada soal dengan 
indikator menginduksi dan mempertimbangkan hasil induksi telah tersedia penjelasan berupa konsep fisika yang dikaitkan dalam kehidupan sehari-hari. Konsep yang menjelaskan jawaban dari pertanyaan sudah tercantum pada soal, sehingga siswa akan lebih mudah menganalisis pernyataan yang tepat untuk menjawab soal tersebut meskipun belum mendapatkan pembelajaran sebelumnya. Setelah proses pembelajaran berlangsung, pengalaman siswa menjadi lebih bertambah dengan diberikan percobaan disetiap pertemuan ataupun demonstrasi, sehingga siswa akan lebih mudah menjawab soal yang konsepnya telah mereka peroleh sendiri saat pembelajaran berlangsung. Secara keseluruhan, kelima indikator keterampilan berpikir kritis mengalami peningkatan dengan kriteria sedang. Hal ini sesuai dengan pernyataan peneliti sebelumnya bahwa ketercapaian tiap indikator keterampilan berpikir kritis dari soal pretest dan postest mengalami peningkatan yang berbeda-beda untuk setiap butir soal. Hal ini disebabkan karena setiap butir soal memiliki tingkat kesukaran yang berbeda-beda. [6]

Penelitian ini sejalan dengan penelitian sebelumnya dengan judul penerapan model inkuiri terbimbing dalam pembelajaran matematika dapat meningkatkan pemahaman konsep dan kemampuan berpikir kritis siswa [7].

Sesuai dengan penelitian terdahulu yang berhasil menunjukkan bahwa model pembelajaran inkuiri terbimbing yang berorientasi pada keaktifan siswa dapat meningkatkan kemampuan berpikir kritis siswa pada mata pelajaran Biologi. Hasil yang didapatkan dari tes akhir menunjukkan bahwa kelas ekperimen lebih tinggi dibandingkan pada tes akhir di kelas kontrol [8]

Berdasarkan semua data yang telah dijabarkan dapat disimpulkan bahwa terdapat pengaruh model pembelajaran inkuiri terbimbing berbantuan alat praktikum sederhana terhadap keterampilan berpikir kritis siswa kelas VIII SMP Negeri 16 Palu. Melalui model pembelajaran ini siswa dilibatkan untuk aktif berpikir dan menemukan secara langsung pengertian atau konsep yang ingin diketahuinya. Oleh karena itu model pembelajaran inkuiri terbimbing berbantuan alat praktikum sederhana dapat dijadikan sebagai salah satu alternatif dalam kegiatan belajar mengajar untuk meningkatkan keterampilan berpikir kritis siswa khususnya pada materi fisika.

Kelebihan dari model pembelajaran ini dibandingkan dengan pembelajaran konvensional adalah keaktifan siswa. Adapun kekurangan dari model pembelajaran ini adalah guru harus sabar membimbing siswa agar menemukan sendiri pengertian atau kosep dari materi yang dipelajari.

\section{KESIMPULAN}

Berdasarkan analisa data hasil penelitian, diperoleh peningkatan keterampilan berpikir kritis yang ditunjukkan oleh nilai n-gain yaitu untuk kelas eksperimen sebesar 54,00 dan untuk kelas kontrol sebesar 43,00. Hasil uji hipotesis (uji t) pada tes akhir diperoleh thitung $=$ 8,56 sedangkan tabel $=1,67$. Hasil ini memperlihatkan bahwa harga thitung tidak berada di dalam daerah penerimaan Ho atau dengan kata lain $\mathrm{H}_{1}$ diterima pada taraf nyata a $=0,05$. Sehingga dapat disimpulkan bahwa terdapat pengaruh model pembelajaran inkuiri terbimbing terhadap keterampilan berpikir kritis pada siswa kelas VIII SMP Negeri 16 Palu.

\section{DAFTAR PUSTAKA}

[1] Depdiknas. Kurikulum 2004, Standar Kompetensi Mata Pelajaran Fisika SMA dan MA.. Jakarta: Departemen Pendidikan Nasional

[2] Liliasari, dan M. Tahil .(2013). "Berpikir Kompleks dan Implementasinya dalam Pembelajaran IPA". Makassar: Universitas Makassar

[3] Supardin. (2012). Pengaruh Model Pembelajaran Student Fasilitator and Explaining terhadap Kemampuan Berpikir Kritis pada Siswa Kelas X SMA Negeri 1 Balaesang. Skripsi pada Fakultas KIP Universitas Tadulako: tidak diterbitkan

[4] Iqbal, Muhammad. (2011). Penerapan Model Pembelajaran Inkuiri Terbimbing pada Materi Getaran dan Gelombang untuk Meningkatkan Hasil Belajar Fisika pada Siswa Kelas VIIIA SMP Negeri 14 Palu.Skripsi pada Fakultas KIP Universitas Tadulako: tidak diterbitkan

[5] Suharsaputra, U. 2012. Metode Penelitian Kuantitatif, Kualitatif dan Tindakan. Bandung: PT Refika Aditama

[6] Nurjannah. (2012). Implementasi Pendekatan SETS untuk meningkatkan Keterampilan Berpikir Kritis pada Siswa Kelas VIII SMP SATAP 3 Tanantovea, Skripsi pada Fakultas KIP Universitas Tadulako: tidak diterbitkan

[7] Karim, A . (2011). Penerapan Model Pembelajaran Inkuiri Terbimbing dalam pembelajaran matematika untuk meningkatkan pemahaman konsep dan kemampuan berpikir kritis siswa SD. Jurnal pendidikan (online), Edisi khusus no 1 , tersedia : http://jurnal.upi.edu/file/3-Asrul-Karim.pdf (28 Maret 2016

[8] Rahmayanti, F. (2015). "Pengaruh Penerapan Model Inkuiri Terbimbing (Guided Inquiry) terhadap Kemampuan Berpikir Kritis Siswa Kelas XI Peminatan Matematika Dan Ilmu-IImu Alam Sman 2 Gerung". Jurnal pendidikan (online), http://jurnal.um.edu/file/3Fitri-Rahmayanti.pdf (28 Maret 2016) 